\title{
A STATUS REPORT ON GEMSTONES FROM AFGHANISTAN
}

By Gary W. Bowersox

Although Afghanistan has historically been well known for its lapis lazuli deposits, significant amounts of fine emerald, tourmaline, kunzite, and some rubies are now emerging from that embattled nation. Emeralds come primarily from the Panishir Valley, northeast of Kabul. Large amounts of green, blue, and pink tourmaline, as well as considerable quantities of kunzite and some aquamarine, have been taken from the pegmatites of the Nuristan region, east of Panjshir. Smaller quantities of fine ruby have been found in the Sorobi region. between Ialalabad and Kabul. The occurrence, mining, and distribution of these gem materials are summarized, as are their gemological properties. Lesser amounts of garnet, amethyst, spinel, and morganite have also been located. The prospects for future production of emeralds and pegmatite gems, in particular, are excellent.

\section{ABOUT THE AUTHOR}

Mr. Bowersox is president of Gem Industries, Inc., in Honolulu, Hawaii; he has been buying and cutting Afghan gem materials for over 12 years.

Acknowledgments: The author particularly wishes to thank the following people for providing information used in this article: Aisha Rind, Badshah. Maula Mohammad Bieg. Haji Gulam Haider, Haji Mohamuddin, Fazal Uddin, and V. Prokofiev. Dr. James Shigley and John Koivula, of the GIA Research Department, contributed information to the sections on geology and gemological properties.

O1986 Gemological Institute of America
A lthough the political situation in Afghanistan conitinues to be very unstable, Afghan miners remove many thousands of carats of fine gems each year from that country. In addition to the historically famous deposits of lapis lazuli, significant quantities of emerald, tourmaline, and kunzite, among other gem materials, have emerged from the Hindu Kush region of Afghanistan within the last few years. Small amounts of fine ruby are also being mined. Most of these gem materials are of very high quality (figure 1). While much has been written about the lapis lazuli from Sar-e-Sang (e.g., Wyart et al., 1981), relatively little has been published about these other gems. To help fill some of the gaps in our knowledge of this area, this article presents a current status report on several Afghan gem materials-emerald, tourmaline, kunzite, and rubyincluding the locations of the mines, mining methods, gemological properties, and some production figures.

\section{THE HINDU KUSH \\ GEM-PRODUCING AREAS}

The mines that have recently produced gem material are for the most part in the northeastern portion of the country, north and east of Kabul, the capital of Afghanistan (figure 2). Emeralds have been found primarily in the Panjshir Valley.* Pegmatite gems-tourmaline, kunzite, and aquamarine-have been found in the Nuristan region, crossing the provinces of Laghman and Konar. Rubies have been found in the southern portion of the Sorobi district, in Kabul Province.

The topography of the region is dominated by the towering Hindu Kush mountain range (figure 3). These mountains form the western end of the Himalayas, which stretch eastward across northern Pakistan and India. The Hindu Kush range is one of the most rugged areas of the world, with mountains reaching up to $6,000 \mathrm{~m}(19,500 \mathrm{ft}$.) separated by narrow, steep river valleys. The road network 


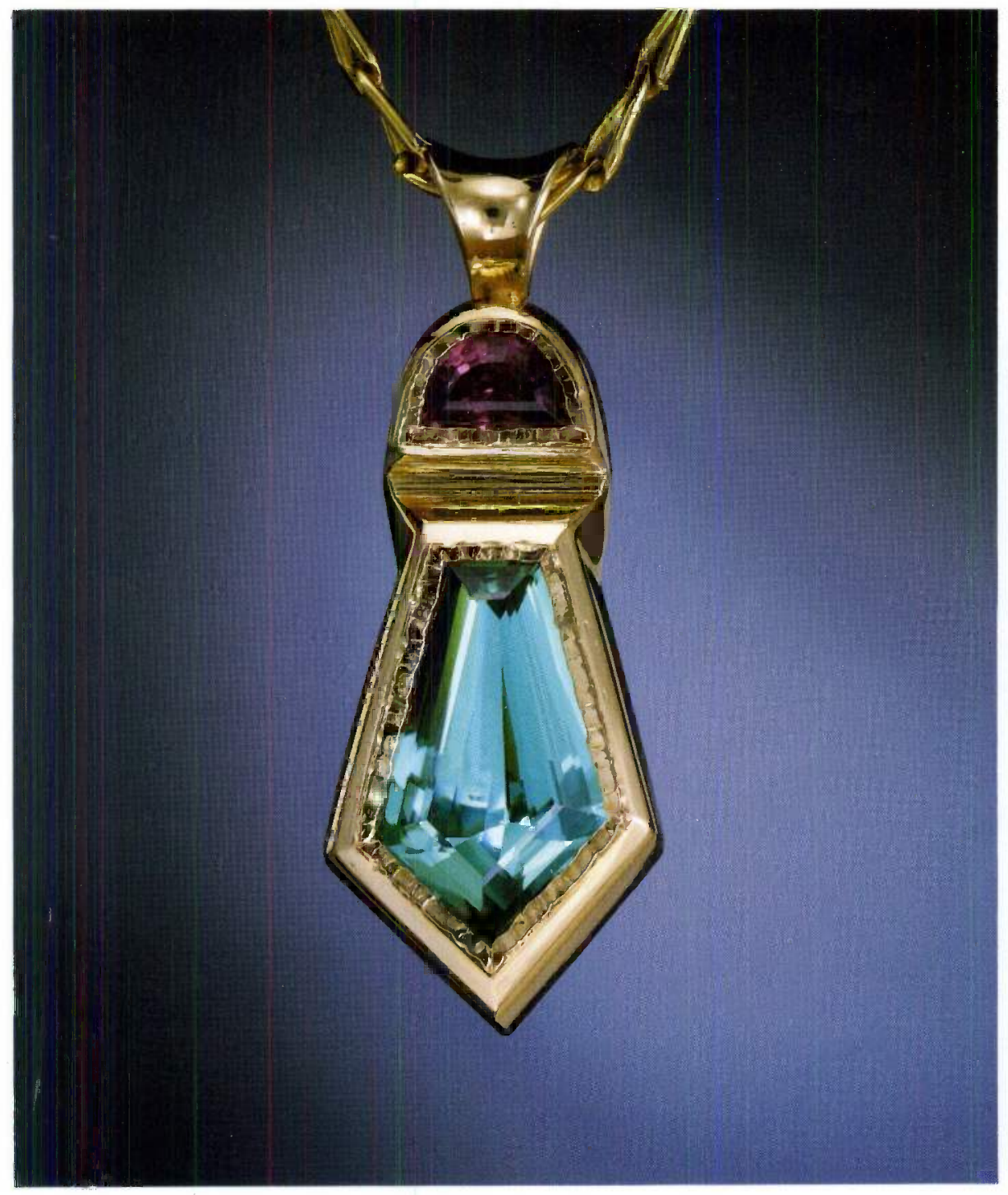

Figure 1. The 13.66-ct blue tourmaline in this pendant exemplifies the fine quality of gem material currently being produced from $A f$ ghanistan. Pendant courtesy of Norma Morein. Photo $\mathbb{C}$ Harold Erica Van Pelt.

is limited, and many areas in this part of Afghanistan are inaccessible except by foot. This, combined with a climate that ranges from extremely cold winters to hot, dry summers, contributes to the inhospitability of the region.

Despite their remoteness, both the Hindu Kush range and the adjacent Karakoram range in neighboring Pakistan have been the sites of spectacular finds of gemstones during the last 15 years.

\footnotetext{
*Note in figure 2 that Panjshir Valley has been placed in Kapisa Province, on the basis of the Rand-McNally (1982) and other recent maps used as references to develop this one. However, many geologic sources refer to Panishir Valley as being in Parvan Province. Note also that the spellings for Afghan place names used in this article are those adopted by Rand-McNally (1982). We have chosen this source for the sake of consistency, al though these names, too, often vary greatly from one reference to another.
}

In addition to earlier descriptions of Panjshir emeralds (Neilson and Gannon, 1977) and of pegmatite gemstones from Nuristan (Bariand and Poullen, 1978), important discoveries of tourmaline, beryl, corundum, and other gemstones have been made in Pakistan in the Gilgit area (Kazni et al., 1985), in the Swat and Hunza valleys northeast of Peshawar (Gübelin, 1982), and in Kashmir (Atkinson and Kothavala, 1983). These areas of Afghanistan and Pakistan are located in one of the most geologically dynamic regions of the worldat the juncture along which the Indo-Pakistan and Asian crustal plates collided to give rise to the Himalayas. The geology of this region is quite complex, and it has been investigated in detail only recently (for further information, see Weippert et al., 1970; Lapparent, 1972; Fuchs et al., 1974; and Wolfart and Wittekindt, 1980|. These 


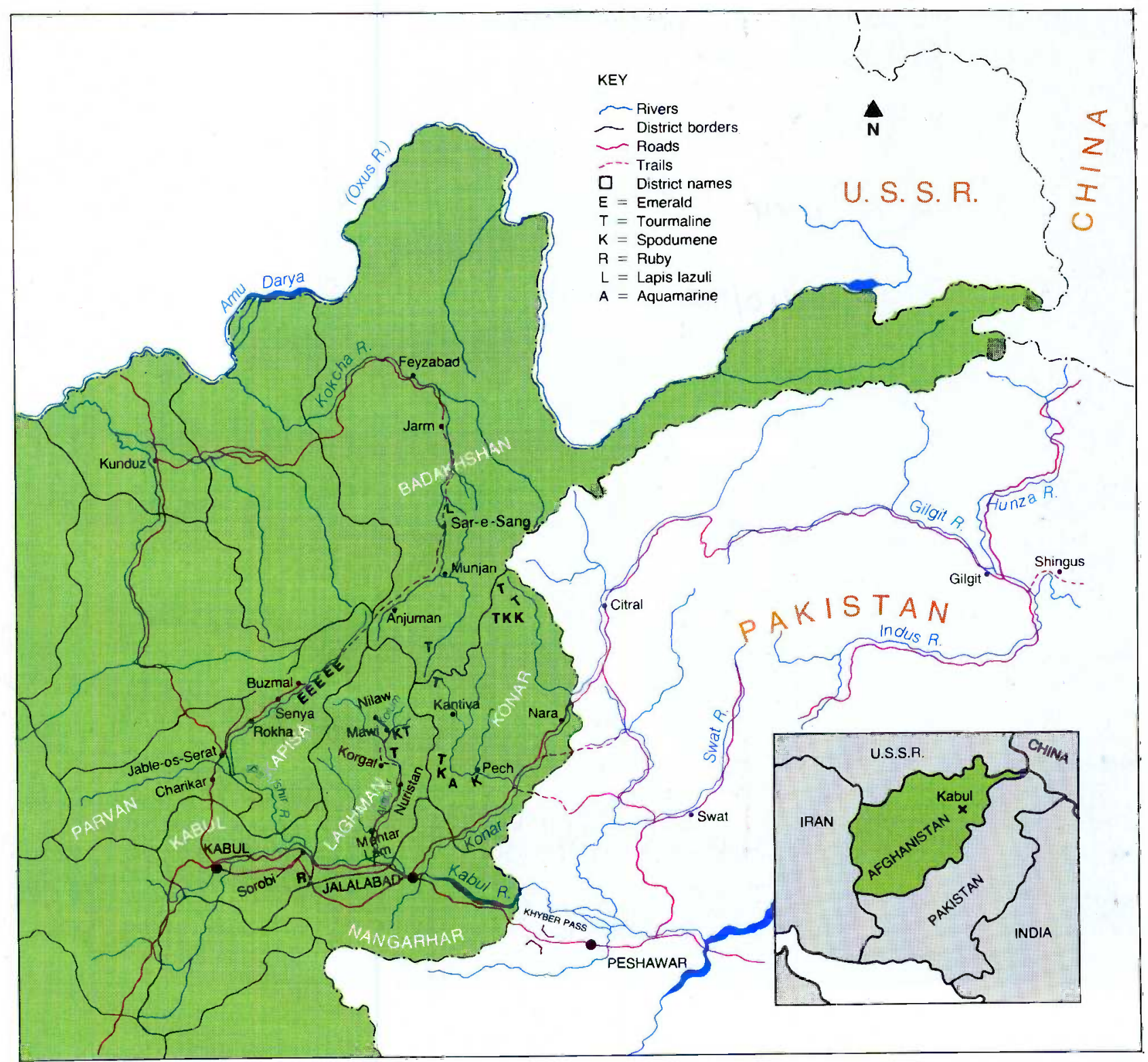

Figure 2. The northeastern provinces of Afghanistan-bordered by the USSR, China, and Pakistan (see inset)-encompass one of the most important gem-producing regions in the world today. Some of the principal localities for emerald, tourmaline, spodumene (kunzite), ruby, lapis lazuli, and aquamarine are labeled $E, T, K, R, L$, and $A$, respectively, on the map.

investigations indicate that the Hindu Kush area represents the western end of a succession of important gem-producing regions that stretch all along the Himalayas through Afghanistan, Pakistan, India, Nepal, and into Burma. Rossovskiy and Konovalenko (1976) have suggested that these separate regions are in fact part of a much larger "South Asian" gem pegmatite belt whose formation can be linked to the sequence of orogenic events that resulted in the formation of the Himalaya range.

Although gem beryl was found during the ar- cheological excavation of an ancient Greek city in northwestern Badakhshan, organized mining of beryl, tourmaline, kunzite, and ruby in Afghanistan dates only from the early 1970s (Dunn, 1974; Bariand and Poullen, 1978). Ostensibly the mines are under government jurisdiction, but most active mining and selling is done by independent miners, usually local tribesmen. Because of the volatility of the current political situation in Afghanistan, the gem-mining areas around Kabul and Jalalabad are virtually inaccessible to foreign gem buyers. Once mined, the uncut crystals of 
Figure 3. The formidable Hindu Kush mountains provide a harsh environment for gem mining, and many remote gem localities are inaccessible except by many miles of travel by foot. The Hindu Kush range forms the western end of the Himalayas and stretches from central Afghanistan to the northern tip of Pakistan. The severe climate in these mountain regions further restricts gem mining. Photo $\mathbb{C}$ Mike Zens.

emerald, tourmaline, spodumene, etc., are smug gled across the border into Pakistan, primarily into tribal Agency areas such as Bajaur (surrounding Peshawar), where most of the trade in Afghan gems is conducted. To enter Afghanistan, or even to travel along the frontier Agency areas of northern Pakistan, one must have special permission from both the government and the local tribal leaders. Such passes are nearly impossible to obtain, and even then there is no guarantee of safety.

This report describes some of the gem materials currently originating in Afghanistan. It is based largely on the author's many years of experience dealing with Afghan gemstones, his previous travels within the country to purchase gemstones, and his recent (September 1985) discussions in Pakistan with several prominent Afghan miners.

\section{THE PANISHIR EMERALDS}

Several thousand carats of fine-quality emeralds, some of which are very similar in color and quality to those from the famous Muzo mine of Colombia, have emerged from Afghanistan in recent years (figure 4). The emerald-mining area of the Panjshir Valley is located approximately 110 (air) $\mathrm{km} 170$ mi.) northeast of Kabul (again, see figure 2). The Panjshir River, a tributary of the Kabul River, bisects a portion of the Hindu Kush mountain range. The emerald-mining district lies along the southern slopes of the Hindu Kush, south of the Panjshir 


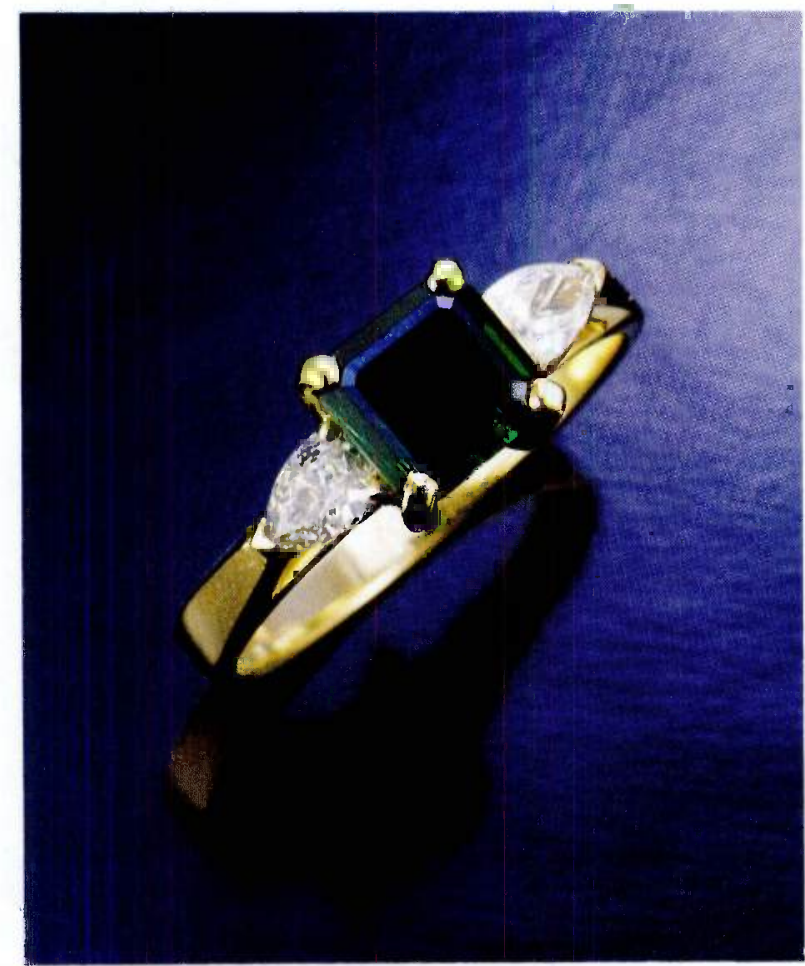

Figure 4. The 1.28-ct emerald in this lady's ring is typical of the dark green material found in the Panishir Valley mines. Stone courtesy of Gem Industries, Inc. Photo (C) Tino Hammid.

River. It currently encompasses six active mines-Darkhenj, Mikeni, Butak, Buzmal, Bakhi, and Darun (Neilson and Gannon, 1977).

Access, Geology, and Mining. Although travel in this area is extremely dangerous at the present time, access to Panjshir from Kabul is fairly straightforward. Travel north by field vehicle 58 $\mathrm{km}$ to Charikar. Fron Charikar, travel $14 \mathrm{~km}$ north to Jable-os-Seraj, then $35 \mathrm{~km}$ northeast along the north side of the Panjshir River to Rokha, then another $29 \mathrm{~km}$ to Senya, and-for the last 19 $\mathrm{km}$-by a poor dirt road to where it ends at the village of Buzmal (Neilson and Gannon, 1977). The Panjshir Valley is densely populated. The emeralds occur at an elevation of 3,000-4,000 m, requiring that the miners walk several hours up the rough slopes $\left(30^{\circ}-40^{\circ}\right.$ angle) as there are no horse or mule trails.

The Panjshir emerald locality has been actively mined only during the last 10 years, with the greatest activity since the early 1980s, although the deposit reportedly was found by Russian geol- ogists in 1970 (Bariand and Poullen, 1978). Within this district, the emeralds occur along small replacement or fracture-filling veins. According to Neilson and Gannon (1977), the veins cut through host rocks consisting of metamorphosed limestones, calcareous slates, phyllites, and micaceous schists of Silurian-Devonian age (400 million years). The veins themselves consist mainly of quartz and albite, and are apparently related in origin to a local igneous intrusive rock described as a quartz-feldspar porphyry. When followed in an exposure, these veins vary in thickness up to 15 $\mathrm{cm}$. Emerald mineralization along and within the veins is distributed sporadically, but is often associated with pyrite, which the miners use as an indication of the emerald. The emerald is believed to be of hydrothermal origin, and apparently resulted from a chemical reaction between solutions traveling along the veins and the enclosing host rocks. According to Mr. Haji Mohamuddin, one of the discoverers of the Buzmal mine, approximately 1,000 workers are mining emeralds throughout the valley; 100 men regularly work Buzmal.

Dynamite is used first to identify where in the host rock the emerald crystals are most likely to be found. The bombings that frequently occur in this area occasionally perform the same function. Using picks and shovels, the miners dig in pits as shallow as one meter and as deep as several meters to extract the individual crystals or specimens. In spite of the extreme weather conditions, the mines are worked virtually all year, the political situation permitting.

Figure 5. This parcel of 87 Afghan emeralds weighs a total of $140.9 \mathrm{ct}$ and displays the range of colors found in the Panishir material. Stones courtesy of Gem Industries, Inc. Photo by G.W. Bowersox.

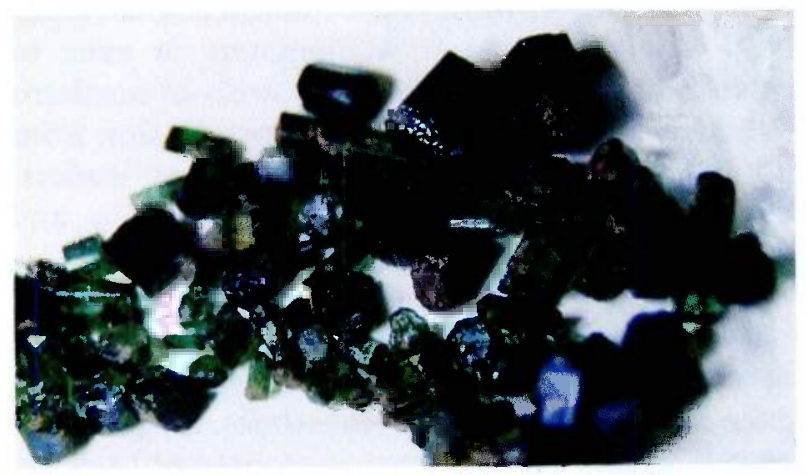




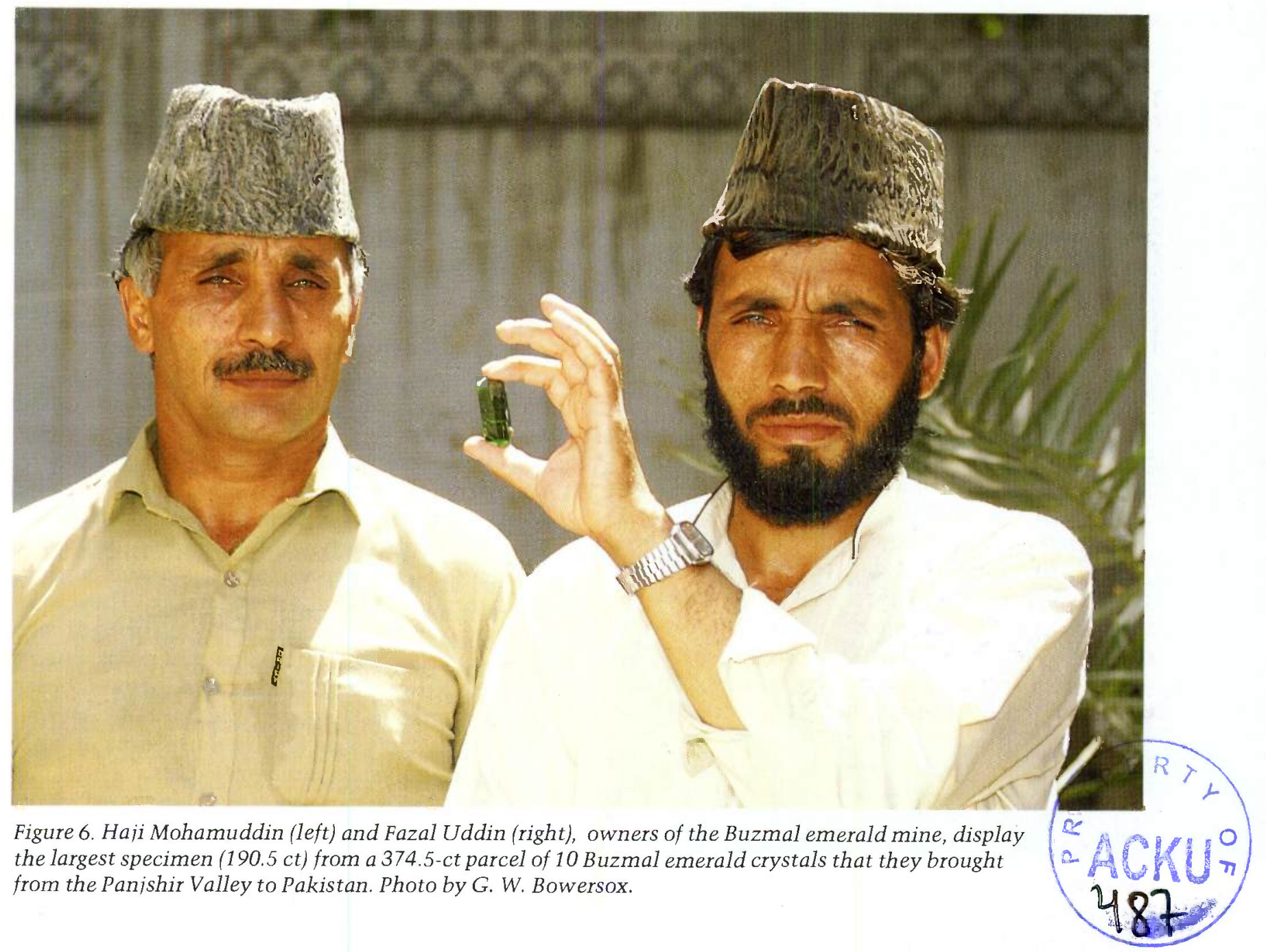

Description of the Material. In general, the Panjshir emeralds are a rich dark green (figure 5). The finest stones are similar in color to the fine emeralds found at the Muzo mine in Colombia. The local miners claim that the Panjshir emeralds of the best color and quality come from the Mikeni and Darkhenj mines.

Gem-quality crystals over 10 ct are common. In fact, a lot of 10 crystals weighing a total of 374.5 ct was recently recovered from the Buzmal mine. The largest of these crystals weighed $190.5 \mathrm{ct}$ (figure 6). Overall, the Panjshir material is larger and cleaner than emeralds found in the Swat (see Gübelin, 1982) and Gilgit regions of Pakistan.

Gemological Properties. A study of the few crystals and cut stones made available for this purpose showed the physical and optical properties to be quite normal for emerald: refractive indices, 1.578 and $1.585( \pm 0.005)$; S.G., $2.71( \pm 0.02)$; inert to ultraviolet radiation; and a typical spectrum with sharp lines at $682,679,660,646,635,612,477$, and $472 \mathrm{~nm}$, and a broad absorption band between 560 and $600 \mathrm{~nm}$. When the crystals were viewed with the microscope, two- and three-phase inclusions, growth zones, and fracturing were visible. It is interesting to note that the refractive indices and specific gravity of this material are somewhat lower than those for emeralds from the nearby Swat Valley in Pakistan (Gübelin, 1982).

Distribution and Production. Most of the Panjshir emeralds are transported (year round) in rough form to refugee camps in northern Pakistan. The trip takes approximately 20 days; all travel is by foot. The border area is particularly dangerous because explosive devices have been scattered throughout. From these camps the stones are purchased by Pakistan buyers from Karachi or by the very few Western buyers who travel to the area.

During the three weeks the author was on the Afghanistan border in September 1985, he viewed 
pink fluorescence. When exposed to short-wave ultraviolet radiation, they exhibited a strong bluish pink fluorescence with a red phosphorescence that lasted for about one minute. When viewed with the microscope, the spodumene fragments revealed three-phase inclusions, growth tubes, and cleavages, and displayed twinning. In general, these properties are identical to those reported for Afghanistan spodumene by Dunn (1974) and Rossovskiy (1981).

Most spodumene exhibits the property of tenebrescence, which involves a reversible darkening and lightening of its color with changes in conditions (Claffy, 1953). Pure spodumene is colorless; the various colors (pink, purple, green, yellow) are due to the presence of trace elements such as manganese and iron. Manganese substitutes for silicon, and iron for aluminum, in the spodumene crystal structure. According to Hassan and Labib (1978) and Nassau (1983), a darkening of the color of spodumene to pink or purple (kunzite) can be brought about by exposure to a source of high-energy radiation (gamma or X-rays) that removes an electron from the manganese and changes its oxidation state from $2^{+}$to $3^{+}$. Further irradiation produces a coupled oxidationreduction reaction involving both iron and manganese to turn the pink spodumene green.

$$
\mathrm{Mn}^{3+}+\mathrm{Fe}^{3+} \stackrel{\text { irradiation }}{\longrightarrow} \mathrm{Mn}^{4+}+\mathrm{Fe}^{2+}
$$

These radiation-induced color changes are thermally unstable, and the color-change sequence described above can be reversed by exposure to daylight, ultraviolet radiation, or moderate heat of a few hundred degrees Celsius. The exact coloralteration behavior of spodumene, and the relative persistence of radiation-induced colors, will vary depending on the nature of the trace elements and the color-treatment history of the stones in question. Because it is colored by chromium, which in spodumene is not susceptible to oxidation or reduction, hiddenite does not exhibit changes in coloration under similar conditions.

When mined, spodumene emerges from the ground with a blue-violet or green color. This suggests that the crystals have been exposed to some natural source of radiation that produced these colors by the mechanism described above. According to the miners, leaving the crystals in the sun for several days, often after having boiled them in water, is sufficient to turn the material to an attractive purple or pink color. Fade tests were con- ducted to document the thermal stability of the purple kunzite, and determined that heating crystal fragments to temperatures of $400{ }^{\circ} \mathrm{C}$ for six hours was adequate to entirely bleach the pink color. Exposure of several pieces from a single pink crystal to direct sunlight produced fading to virtually colorless within several days (less than a week). As described above, the pink color can be restored by re-irradiation.

Distribution and Production. The mined crystals of tourmaline and spodumene are carried on the backs of the miners, who usually travel by foot approximately $560-640 \mathrm{~km}$ (350-400 mi.) over rough mountain terrain and through a border area dotted with land mines to reach Pakistan. The author purchased most of his material from miners whose primary trading area is the Bajaur Agency.

The Nuristan region has produced hundreds of thousands of carats of gem-quality tourmaline since 1980 . The author estimates that approximately $2,000 \mathrm{~kg}$ of fine kunzite are being mined each year.

\section{JEGDALEK RUBY}

Although very little mining is being conducted at the current time because the area is so volatile politically, a number of fine rubies have been mined from the southern portion of the Sorobi district (again, see figure 2). Local miners refer to the main deposit as the Jegdalek mine. Although little research has been done on the geology of the ruby-producing area and the occurrence of the rubies, it is known that they are usually found in situ in marble cut by granitic intrusions of Oligocene age (Afzali, 1981). The crystals range in color from a light purple-red to a deep "pigeon's blood" red (figure 11). The best-quality stones are similar to those found at Mogok, in Burma. The author has seen fair-quality faceted stones as large as $10 \mathrm{ct}$, although top-quality rubies from this area rarely exceed $5 \mathrm{ct}$.

While current supplies appear to be small-the author saw fewer than $100 \mathrm{ct}$ of gem-quality material during his most recent visit-communications from the miners indicate that the reserves are significant. Larger amounts of this material will most likely be available once the political situation in the area stabilizes.

Gemological Properties. Examination of a small number of cut stones and crystal fragments of ruby 
Bariand and Poullen (1978) describe the intense shades of blue and green tourmaline as the most valued. The cuttable crystals, which range up to 15 $\mathrm{cm}$ in length and $4 \mathrm{~cm}$ in width, also represent magnificent mineral specimens in themselves. For the most part, these crystals are well formed, often clean and free of inclusions and fractures, and, at the time they are purchased for cutting, are free of matrix. Color zoning perpendicular to the length of the crystal varies from sharp color transitions to a smooth grading of one color in to another. Most of the crystals examined in this study were not color zoned.

Some data have been published on the Nuristan tourmalines. Leckebusch (1978) reported chemical compositions of these tourmalines, which are elbaites, and related the color zonation in individual crystals to variations in chemistry. Dunn (1974) examined a range of tourmalines from this area, in particular the colorless crystals, or achroites. For pale to deeply colored crystals, he reported refractive indices of 1.617 and 1.639 $( \pm 0.003)$ with no particular correlation of these values with color. For the achroites, the indices were 1.615 and 1.633. The specific gravity ranged from 3.02 to 3.07 .

Examination of a parcel of green, blue-green, and blue tourmalines revealed refractive indices of 1.619 and 1.639 and specific-gravity values of 3.04-3.09. The crystals displayed grayish blue to greenish blue pleochroism. They were inert to

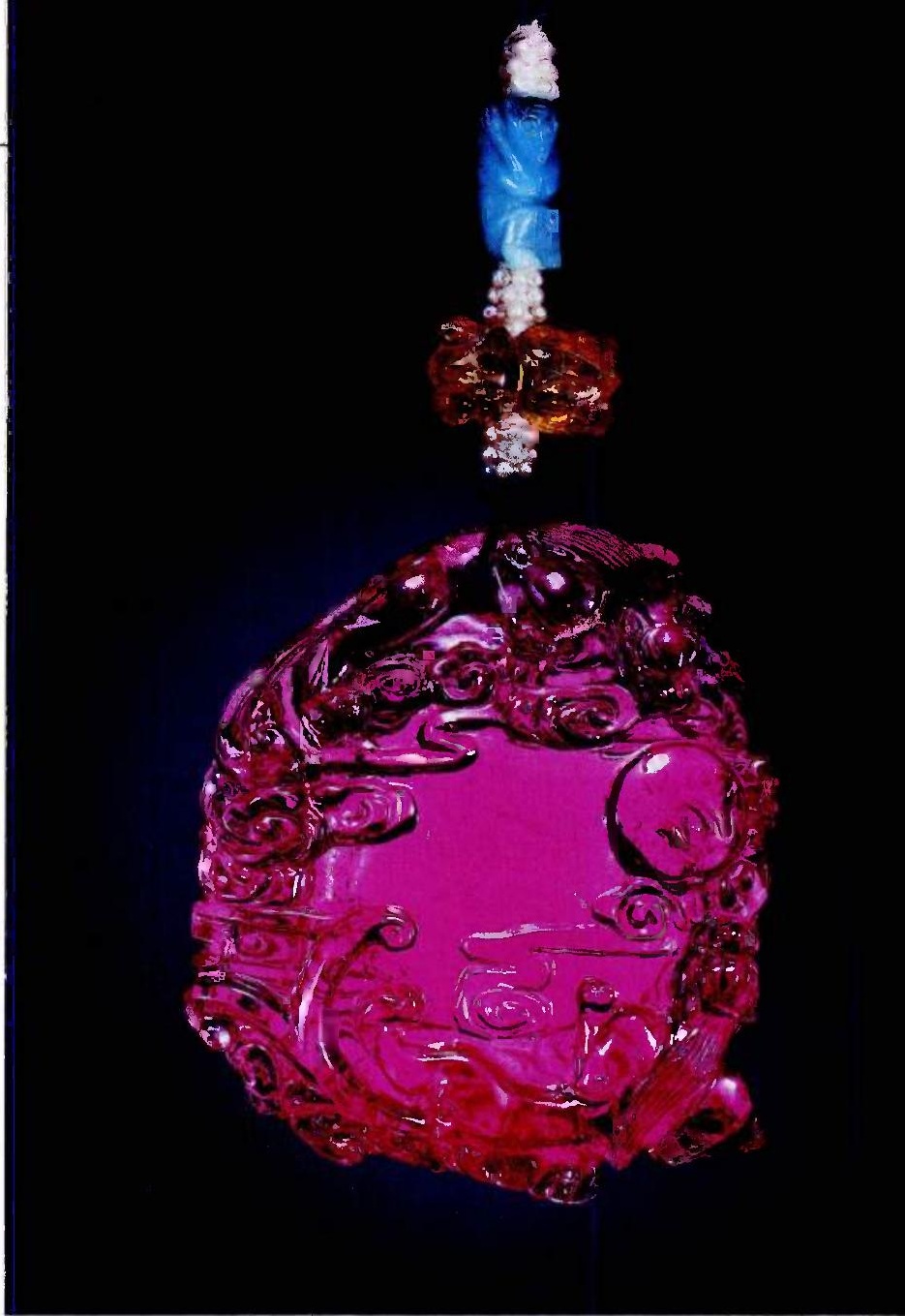

Figure 7. This 200-ct carved rubellite exemplifies some of the finest tourmaline produced by the Nuristan region. The pendant was carved by Hing Wa Lee. Photo $(\mathcal{C}$ Harold et Erica Van Pelt.

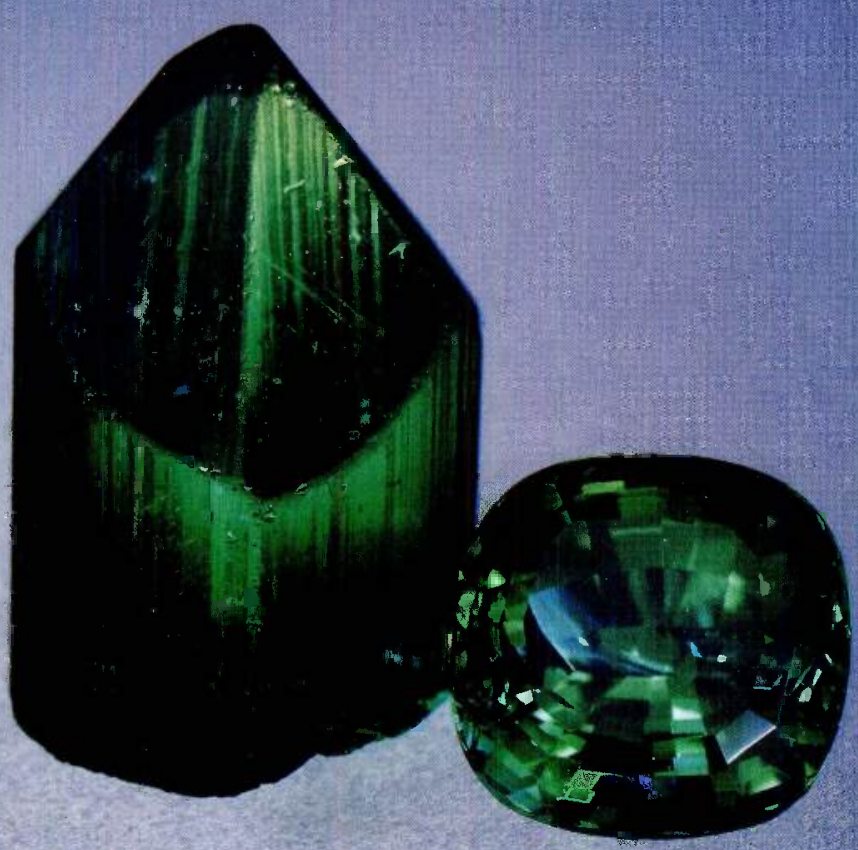

Figure 8. The intense green of this 12.25-ct cut tourmaline and accompanying $13 \times 19 \mathrm{~mm}$ gem-quality crystal is one of the exceptional colors typical of the best Afghan material. These specimens are also representative of the high clarity frequently encountered in Nuristan tourmalines. Stones courtesy of Afghan Gems, San Francisco, CA. Photo $(\mathcal{C}$ Harold $\Theta$ Erica Van Pelt.

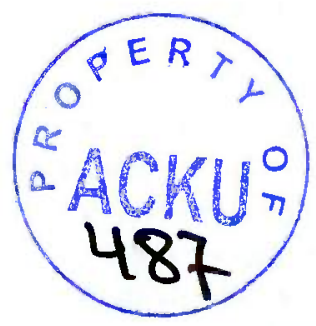




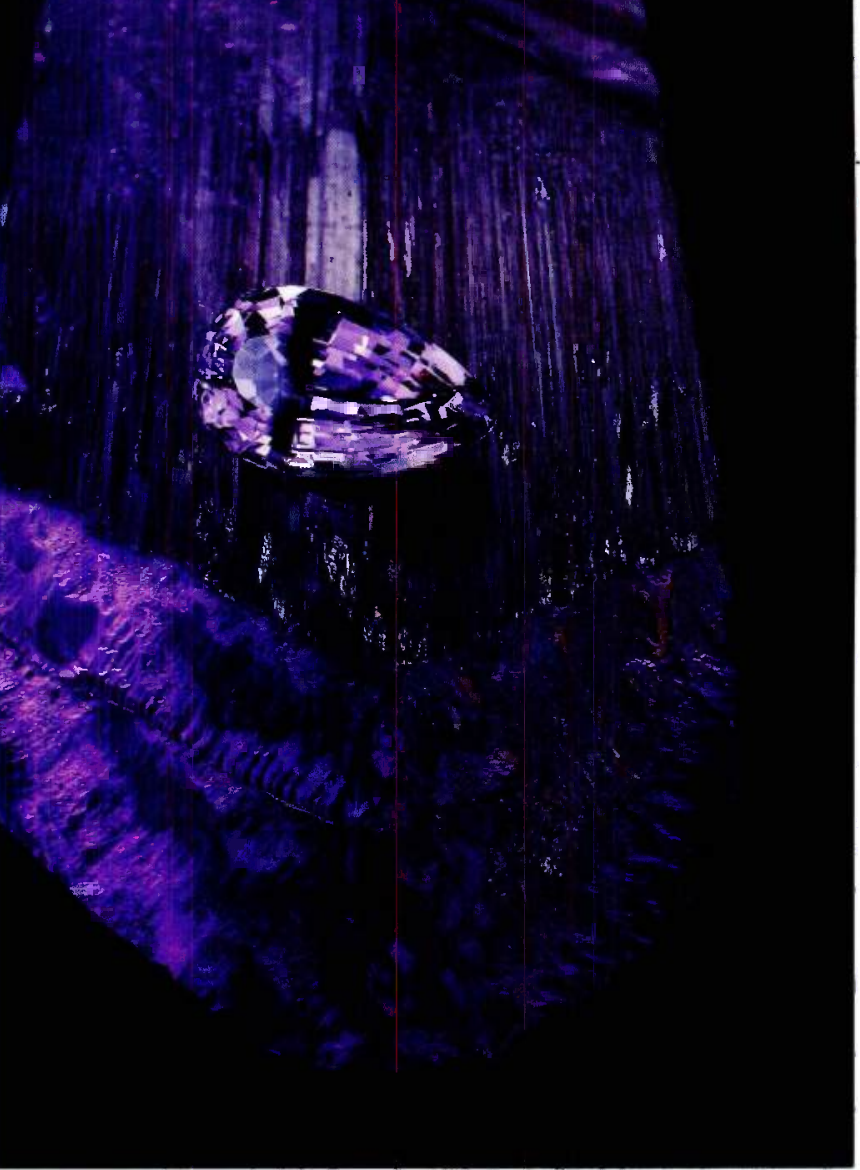

Figure 9. The Nuristan region also produces some of the finest kunzite crystals ever found, as can be seen from the 1243.7-gram crystal depicted here with a 45.07-ct pear-shaped gem cut from similar rough. The crystal displays its most intense color as viewed here along the c-axis.

Stones courtesy of Gem Industries, Inc. Photo $\mathbb{C}$ Harold e) Erica Van Pelt.

long- and short-wave ultraviolet radiation, except for some of the color-zoned crystals that were weakly fluorescent with a chalky bluish color under short-wave at the pale end of the crystal. Two-phase inclusions, fractures, and color zoning were visible with the microscope. In the hand spectroscope, bands at 495,490 and $440 \mathrm{~nm}$ were present in the blue crystals, with an additional band at $540 \mathrm{~nm}$ present when the stone being examined was oriented perpendicular to the c-axis. The spectra displayed total absorption above 598 $\mathrm{nm}$. The most distinctive feature of these tourmalines is their attractive blue to green color.

Spodumene. The spodumene crystals from the Nuristan region are among the finest examples of this mineral ever found (figure 9). Many details on the pegmatite deposits of spodumene are given in Rossovskiy et al. (1978) and Bariand and Poullen (1978). The transparent, gem-quality spodumene crystals from Nuristan come in a wide range of

colors-purple and pink (figure 10), as well as blue, green, and yellow. Some of these crystals are up to one meter in length. In general, they are well formed, with large, flat crystal faces, relatively sharp edges, a tabular shape, and are often twinned. As with tourmaline, the spodumene crystals are free of any attached minerals at the time they are sold to gem buyers. As is typical of spodumene, which is pleochroic, the crystals from this area display different hues when viewed in different orientations, with the strongest color for light passing parallel to the long direction (c-axis) of the crystal. Dunn (1974) describes some of the crystals as color zoned, but the crystals examined for this paper were more or less of uniform color.

From the study of a parcel of light pink spodumene crystal fragments and several additional faceted stones, refractive indices of 1.659 and $1.677( \pm 0.003)$ and specific-gravity values of approximately $3.20( \pm 0.02)$ were found. These fragments were pleochroic from brownish pink to pink. No features were visible in the hand spectroscope. When exposed to long-wave ultraviolet radiation, the fragments displayed a strong orangy

Figure 10. These three marquise-cut kunzites exhibit the variety of natural hues that are found in the Nuristan material. Counterclockwise from the top, these gems weigh 290.87, 58.52, and 40.88-ct, respectively. The stones are courtesy of Meredith Mills, Casper, WY. Photo (C Harold e) Erica Van Pelt.

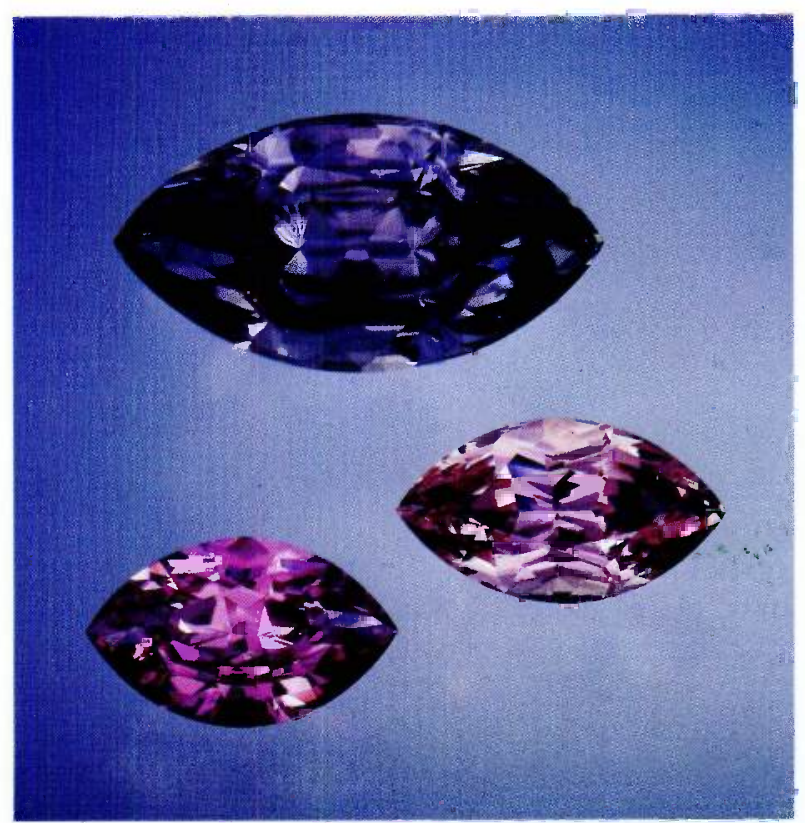


pink fluorescence. When exposed to short-wave ultraviolet radiation, they exhibited a strong bluish pink fluorescence with a red phosphorescence that lasted for about one minute. When viewed with the microscope, the spodumene fragments revealed three-phase inclusions, growth tubes, and cleavages, and displayed twinning. In general, these properties are identical to those reported for Afghanistan spodumene by Dunn (1974) and Rossovskiy (1981).

Most spodumene exhibits the property of tenebrescence, which involves a reversible darkening and lightening of its color with changes in conditions (Claffy, 1953). Pure spodumene is colorless; the various colors (pink, purple, green, yellow) are due to the presence of trace elements such as manganese and iron. Manganese substitutes for silicon, and iron for aluminum, in the spodumene crystal structure. According to Hassan and Labib (1978) and Nassau (1983), a darkening of the color of spodumene to pink or purple (kunzite) can be brought about by exposure to a source of high-energy radiation (gamma or X-rays) that removes an electron from the manganese and changes its oxidation state from $2^{+}$to $3^{+}$. Further irradiation produces a coupled oxidationreduction reaction involving both iron and manganese to turn the pink spodumene green.

$$
\mathrm{Mn}^{3+}+\mathrm{Fe}^{3+} \stackrel{\text { irradiation }}{\longrightarrow} \mathrm{Mn}^{4+}+\mathrm{Fe}^{2+}
$$

These radiation-induced color changes are thermally unstable, and the color-change sequence described above can be reversed by exposure to daylight, ultraviolet radiation, or moderate heat of a few hundred degrees Celsius. The exact coloralteration behavior of spodumene, and the relative persistence of radiation-induced colors, will vary depending on the nature of the trace elements and the color-treatment history of the stones in question. Because it is colored by chromium, which in spodumene is not susceptible to oxidation or reduction, hiddenite does not exhibit changes in coloration under similar conditions.

When mined, spodumene emerges from the ground with a blue-violet or green color. This suggests that the crystals have been exposed to some natural source of radiation that produced these colors by the mechanism described above. According to the miners, leaving the crystals in the sun for several days, often after having boiled them in water, is sufficient to turn the material to an attractive purple or pink color. Fade tests were con- ducted to document the thermal stability of the purple kunzite, and determined that heating crystal fragments to temperatures of $400^{\circ} \mathrm{C}$ for six hours was adequate to entirely bleach the pink color. Exposure of several pieces from a single pink crystal to direct sunlight produced fading to virtually colorless within several days (less than a week). As described above, the pink color can be restored by re-irradiation.

Distribution and Production. The mined crystals of tourmaline and spodumene are carried on the backs of the miners, who usually travel by foot approximately $560-640 \mathrm{~km}$ (350-400 mi.) over rough mountain terrain and through a border area dotted with land mines to reach Pakistan. The author purchased most of his material from miners whose primary trading area is the Bajaur Agency.

The Nuristan region has produced hundreds of thousands of carats of gem-quality tourmaline since 1980. The author estimates that approximately $2,000 \mathrm{~kg}$ of fine kunzite are being mined each year.

\section{JEGDALEK RUBY}

Although very little mining is being conducted at the current time because the area is so volatile politically, a number of fine rubies have been mined from the southern portion of the Sorobi district (again, see figure 2). Local miners refer to the main deposit as the Jegdalek mine. Although little research has been done on the geology of the ruby-producing area and the occurrence of the rubies, it is known that they are usually found in situ in marble cut by granitic intrusions of Oligocene age (Afzali, 1981). The crystals range in color from a light purple-red to a deep "pigeon's blood" red (figure 11). The best-quality stones are similar to those found at Mogok, in Burma. The author has seen fair-quality faceted stones as large as $10 \mathrm{ct}$, although top-quality rubies from this area rarely exceed $5 \mathrm{ct}$.

While current supplies appear to be small-the author saw fewer than 100 ct of gem-quality material during his most recent visit-communications from the miners indicate that the reserves are significant. Larger amounts of this material will most likely be available once the political situation in the area stabilizes.

Gemological Properties. Examination of a small number of cut stones and crystal fragments of ruby 
A single deposit of garnets has been found at Pachighram, in Nangarhar Province. Well-formed crystals of dark red almandine occur in Proterozoic schists. The garnet-bearing schists cover an area approximately $160-240 \mathrm{~km}$ wide and $800-1,100$ $\mathrm{km}$ long (Afzali, 1981). However, the author has not seen any Afghan garnet for sale in the Pakistan trading centers during the last three years.

Small quantities of aquamarine are currently being mined in the area of Gur Salak, in Konar Province. The rough material occurs in pegmatites as well-formed crystals up to $2 \mathrm{~cm}$ thick and $7.5 \mathrm{~cm}$ long $(1 \times 3$ in.). The crystals range in color from light blue to dark blue as well as various intensities of blue-green (figure 14).

The author observed a few morganite crystals during his most recent trip. These crystals, which ranged in color from pink to brownish pink to peach, were reported by Afghan miners to come from the mine at Mawi, in the Nuristan region. Spinel has historically been reported from Badakhshan, northeast of the lapis mines (Scalisi and Cook, 1983), but little spinel has been seen in recent years. A 1970s edition of Afghan Development in Brief, published by the Afghan government, reported that amethyst had been found in both Badakhshan and Kandar. The author has not, however, seen any of this material in the local gemstone market.

produced the following properties of a typical stone: refractive indices, 1.762 and 1.770 ; specific gravity, approximately 4.00 ; moderate to strong fluorescence to long- and short-wave ultraviolet radiation; and purplish red to orangy-red pleochroism. In the hand spectroscope, absorption bands were visible at $469,473,660,668,693$, and $694 \mathrm{~nm}$, and a broad band from 520 to $560 \mathrm{~nm}$. Under the microscope, fractures, small unidentified crystals, and needles thought to be boehmite were generally abundant. Some twinning was also noted. The most interesting feature was a strong blue color zoning present in some of the rubies (figure 12).

\section{OTHER GEM MATERIALS FROM AFGHANISTAN}

Much has been written about lapis lazuli from Afghanistan (e.g., Wyart et al., 1981). In recent years, however, the production and supply of lapis from Badakhshan has been greater than ever before, and many examples of superb material can be seen in gem markets worldwide (figure 13). In 1981, reserves of 1,300 tons were estimated (Afzali, 1981).

\section{CONCLUSION}

Significant quantities of a variety of high-quality gem materials are now emerging from northeastern Afghanistan. More material than ever before

Figure 12. Unusual zones of strong blue color can be observed in some rubies from the legdalek mine. Dark-field illumination, magnified $35 \times$. Photo by John Koivula.

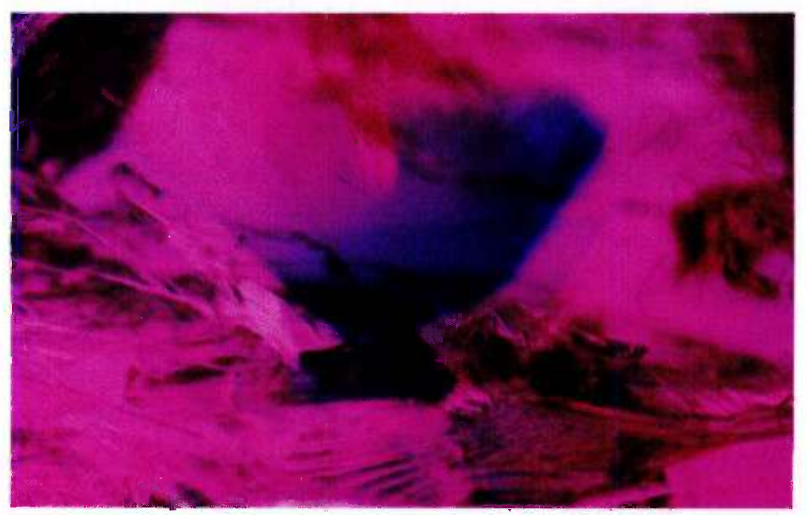




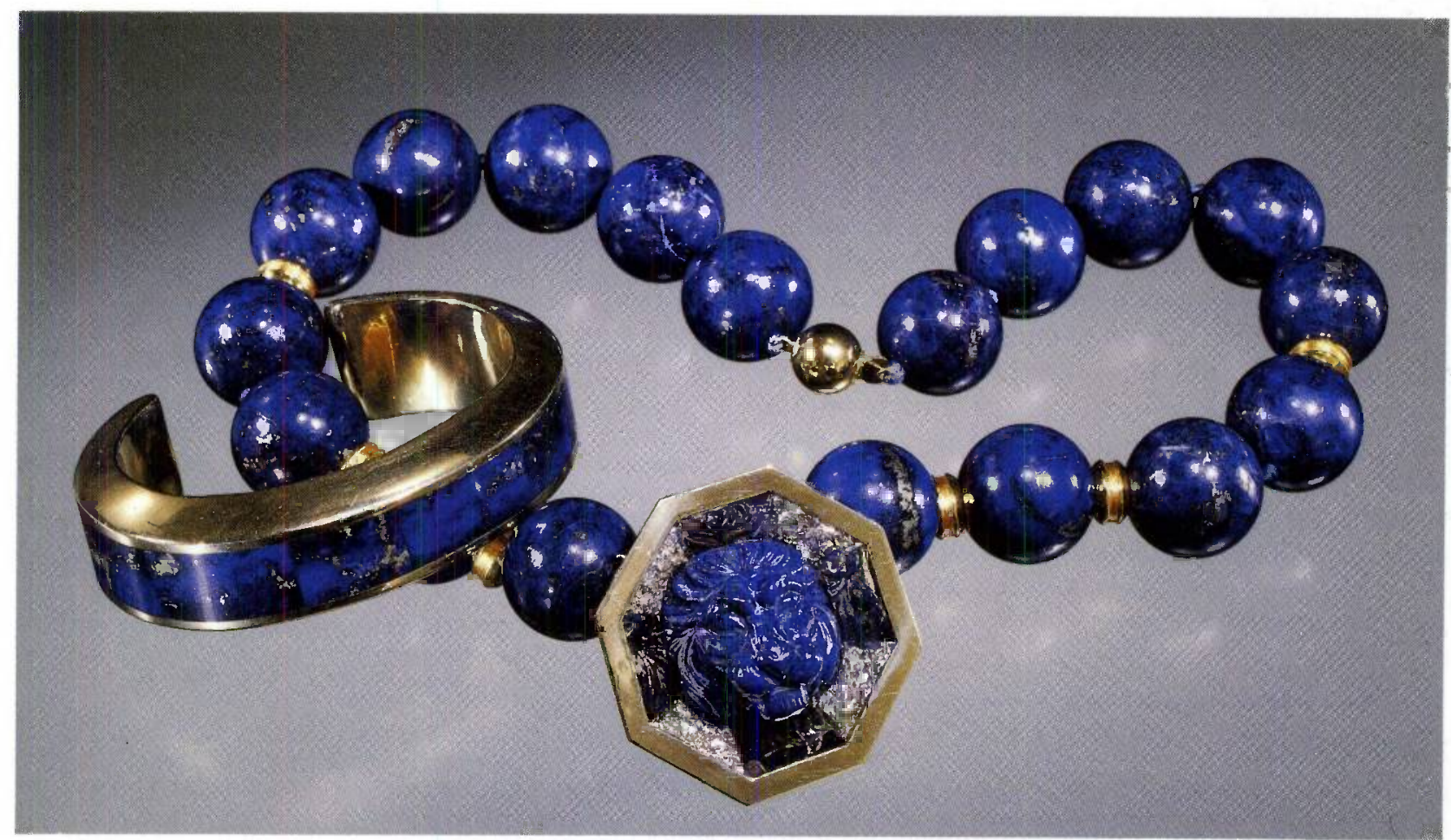

Figure 13. The fine lapis lazuli currently coming from Afghanistan is well represented by the 16-mmwide cuff bracelet and 17- $\mathrm{mm}$ bead necklace with carved lapis and diamond pendant-clasp (35-mm diameter) illustrated here. Photo (c) Harold e) Erica Van Pelt.

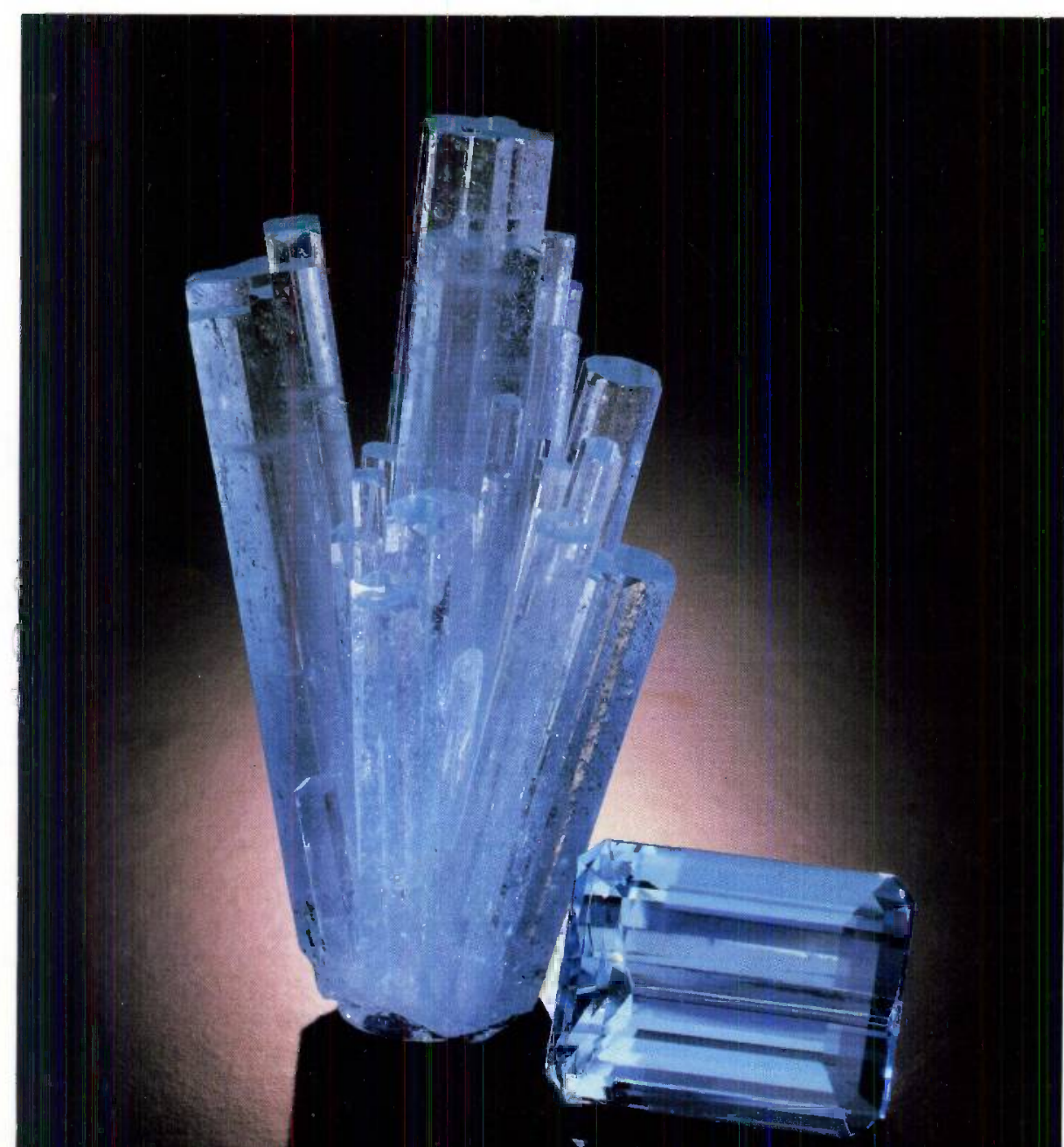

Figure 14. This 5.7-cm-high crystal cluster, accompanied by a 75.8-ct faceted stone, is repesentative of the fine aquamarine that is also being mined in the Nuristan region of Afghanistan. Specimen courtesy of William Larson, Pala, CA; cut stone courtesy of the Los Angeles County Museum of Natural History. Photo (C) Harold et Erica Van Pelt. 
has reached cutting centers in Thailand, Hong Kong, Germany, Brazil, and the U.S. While the present hostilities and war-like conditions in Afghanistan have made mining and subsequent transportation of the gem materials difficult, the need for capital appears to have stimulated mining operations to their greatest heights in many years. For example, greater amounts of fine-quality lapis lazuli are available now than at any time in recent decades. The reserves of tourmaline and spodumene, in particular - and to a lesser extent also emerald-appear to be good. Political conditions permitting, Afghanistan should continue to supply significant quantities of these gem materials for several years to come.

\section{REFERENCES}

Afzali H. (1981) Les ressources d'hydrocarbures, de métaux et de substances utiles de l'Afghanistan: aperçu génerál. Chronique de la Recherche Minière, No. 460, pp. 29-49.

Atkinson D., Kothavala R.Z. (1983) Kashmir sapphires. Gems (4) Gemology, Vol. 19, No. 2, pp. 64-76.

Bariand P., Poullen J.F. (1978) The pegmatites of Laghman, Nuristan, Afghanistan. Mineralogical Record, Vol. 9, No. 5, pp. 301-308.

Claffy E.W. (1953) Composition, tenebrescence, and luminescence of spodumene minerals. American Mineralogist, Vol. 38 , pp. 919-931.

Dunn P.J. (1974) Gem spodumene and achroite tourmaline from Afghanistan. Journal of Gemmology, Vol. 14, No. 4, pp. 170-174.

Fuchs G., Matura A., Scherman O. (1974) Vorbericht über geologische und lagerstättenkundliche Untersuchungen in Nurestan, Afghanistan. Verhanglungen Geologische Bundesanstalt, No. 1, pp. 9-23.

The Great Geographical Atlas (1982). Rand McNally \& Co., Chicago, IL.

Gübelin E.J. (1982) Gemstones of Pakistan: emerald, ruby, and spinel. Gems \&) Gemology, Vol. 18, No. 3, pp. 123-129.
Hassan F., Labib M. (1978) Induced color centers in alphaspodumene called kunzite. Neues Jahrbuch für Mineralogie Abhandlungen, Vol. 134, No. 1, pp. 104-115.

Kazni A.H., Peters J.J., Obodda H.P. (1985) Gem pegmatites of the Shingus-Dusso area, Gilgit, Pakistan. Mineralogical Record, Vol. 16, No. 5, pp. 393-411.

Lapparent A.F. de (1972) Esquisse géologique de l'Afghanistan. Revue de Géographie Physique et de Geologie Dynamique, Vol. 14, No. 4, pp. 327-344.

Leckebusch R. (1978) Chemical composition and colour of tourmalines from Darre Pěch (Nuristan, Afghanistan). Neues Jahrbuch für Mineralogie Abhandlungen, Vol. 133, No. 1 , pp. $53-70$.

Nassau K. (1983) The Physics and Chemistry of Color. J. Wiley and Sons, New York.

Neilson J.B., Gannon P.J. (1977) Mineral evaluation project Afghanistan: Volume 2, significant mineral occurrences. United Nations Development Programme AF G/74/002, Toronto, Canada.

Rossovskiy L.N. (1981) Rare-metal pegmatites with precious stones and conditions of their formation (Hindu Kush). International Geology Review, Vol. 23, No. 11, pp. $1312-1320$.

Rossovskiy L.N., Chmyrev V.M., Salakh A.S. (1976) New fields and belts of rare-metal pegmatites in the Hindu Kush (Eastern Afghanistan). International Geology Review, Vol. 18, No. 11, pp. 1339-1342.

Rossovskiy L.N., Konovalenko S.I. (1976) South Asian pegmatite belt. Akademiia Nauk SSSR Doklady, Earth Science Section, Vol. 229, pp. 89-91.

Rossovskiy L.N., Makagon V.M., Kuz'mina T.M. (1978) Characteristics of the formation of a kunzite deposit in Afghanistan. Soviet Geology and Geophysics, Vol. 19, pp. $82-87$.

Scalisi P., Cook C. (1983) Classic Mineral Localities of the World: Asia and Australia. Van Nostrand Reinhold, New York.

Sinkankas J. (1981) Emerald and Other Beryls. Chilton, Radnor, PA.

Weippert D., Wittekindt H., Wolfart R. (1970) Zur geologischen Entwicklung von Zentral- und Sudafghanistan. Geologisches Jahrbuch, Beihefte, Vol. 92, pp. 1-99.

Wolfart R., Wittekindt H. (1980) Geologie von Afghanistan. Gebruder Borntraeger, Berlin.

Wyart J., Bariand P., Filippi J. (1981) Lapis lazuli from Sar-eSang, Badakhshan, Afghanistan. Gems \&) Gemology, Vol. 17 , No. 4 , pp. $184-190$.
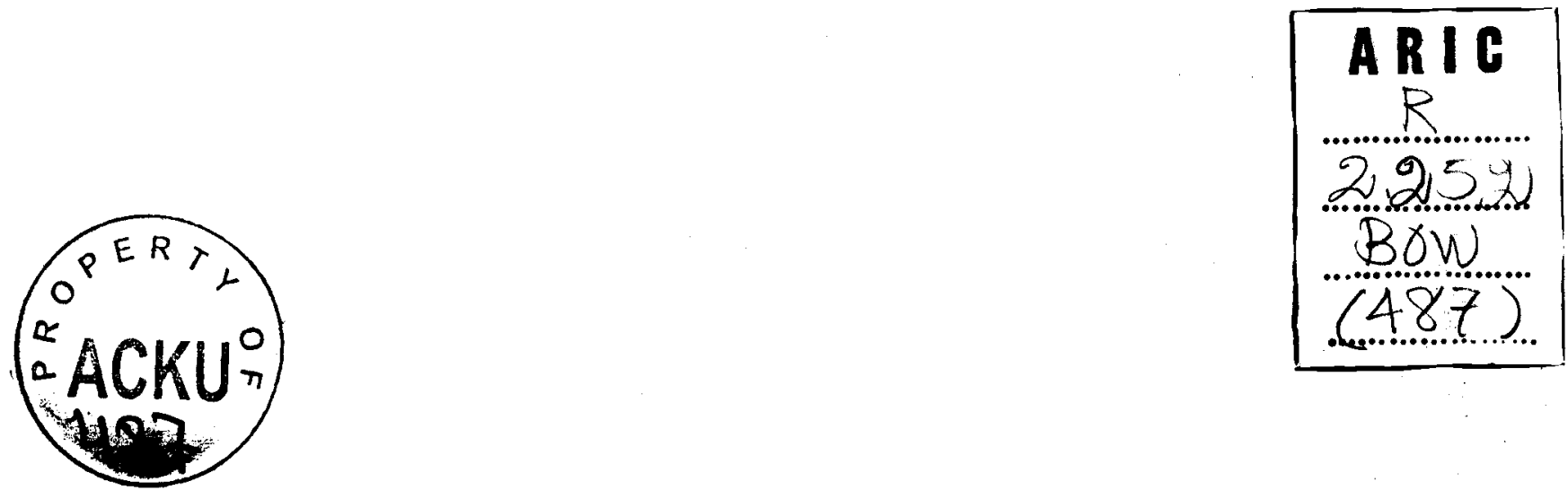